\title{
Newness as a Winning Formula for New Political Parties
}

\author{
Allan Sikk \\ School of Slavonic and East European Studies \\ University College London \\ Gower Street \\ London WC1E 6BT \\ United Kingdom \\ e-mail: a.sikk@ucl.ac.uk \\ tel: $+44(0) 2076794872$ \\ fax: +44(0) 2076798777
}

\section{Acknowledgments}

Earlier versions of the article were presented at the ICEESS World Congress, Berlin, 25-30 July 2005 and ECPR General Conference, Budapest, 8-10 September 2005. The author is grateful to the participants of the panels, Rein Taagepera, Seán Hanley and Vello Pettai for helpful comments. The research for this paper was assisted by the Targeted Financing Grant 0182573 s03 of the Estonian Science Foundation.

Word count 7,983 


\begin{abstract}
Previous studies on new political parties have assumed that they either represent new or ignored cleavages or issues, or emerge in order to cleanse an ideology deficiently represented by an existing party. Four highly successful parties analysed in this article manifestly fail to comply with these assumptions. The article proposes a parsimonious two-dimensional typology of new parties refining the one suggested by Lucardie (2000), incorporating a new type of parties based on the project of newness. We show that the four parties analysed fall into the latter category as they fought on the ideological territory of existing parties yet did not attempt to purify an ideology. It is argued that newness has been an appealing project for new and rejuvenating parties everywhere and the experiences from new democracies should be taken seriously also by those working on established democracies.
\end{abstract}

KEY WORDS: new parties, typological construction, cleavages, issues, expert survey 
Most studies on new parties in Western Europe have had the social cleavage based model of party system development (Lipset \& Rokkan 1967) as an implicit or explicit cornerstone. It has been commonly assumed or concluded that the demand for new parties is related to social heterogeneity, social or value change in a country, or the rise of new issues inadequately represented by established parties (see Harmel \& Robertson 1985, Hauss \& Rayside 1978, Müller-Rommel 2002, Kitschelt 1988, 1995, Hug 1996, 2001). Ferdinand Müller-Rommel's review of Hug (2001) underscores the point: 'we know that new parties emerge primarily because old parties have failed to absorb new issues into their agendas and programmes' (2002: 741). The idea that new parties appear when existing parties become too distant from substantial segments of voters in terms of policy also underlies spatial approaches to political competition (Laver 2005: 280). Other studies on new political parties either have not explicitly assessed the question of issues or cleavages (Tavits 2006, Willey 1998) or have noted the more general disappointment with incumbents as a factor behind new party emergence (Tavits 2007, Krouwel \& Bosch 2004). In one of the major volumes on new political parties, Simon Hug (2001) takes their emergence to be a sign that the old parties have failed to incorporate new issues or assimilate new cleavages. He even argues that new parties would never appear if the old parties were fully knowledgeable of the popularity of the newcomer or aware of the new issues, as it would always be rational to incorporate the issues the new parties stand for (ibid: 50).

Tavits (2008), Lucardie (2000), Krouwel \& Lucardie (2008) and Rochon (1985) are among the few authors who have explicitly considered the possibility that new parties may actually not be based on a new issue, but may enter the party political 
landscape on the territory occupied by established parties. Tavits (2008) assesses the influence of new party entry on the electoral fate of programmatically close established parties. Lucardie and Rochon suggest that challenger or purifier parties arise to 'cleanse' an ideology (Lucardie 2000) or compete with established parties for an already mobilized part of electorate (Rochon 1985).

Lucardie's (2000) typology includes two other types of new political parties. The prophets advocate a new ideology and hence best fit with the traditional conceptions about new parties. Prolocutors are not linked to ideologies but aim to represent a particular issue or an interest in a society. The typology can be represented along two dimensions (see Table 4). First, one has to consider whether a new party has a strong ideological motivation or not. Some may be rooted in a fairly cohesive and comprehensive set of policies that they wish to pursue when in government; such parties fall into the categories of the purifiers and the prophets. They differ from each other essentially based on whether the ideology that motivates them is already but poorly represented by established parties (purifiers) or it is new (prophets). Other parties put forward more limited or less cohesive sets of policy proposals. The prolocutors essentially address a single issue or interest that is of some interest in a given society disregarded by established actors. However, one quarter of the schema remains empty - could any real world new parties have been subscribing to an ideology represented by established political actors yet not have it as their main motivator and the bone of contention with old parties?

[Table 1 about here] 
In this article, we propose a refinement and an extension to Lucardie's original schema presented in Table 1 . We pin down a number of highly relevant new parties with a broad set of policies similar to established parties yet without ideological motivation. Such parties based on the project of newness do not attempt to salvage an ideology - as the purifiers do - yet differ from prolocutors in that they wilfully fight on an already occupied ideological territory. In other words, the parties based on the project of newness can be conceived of as 'purifiers-light' - as they wish to change just the manners of doing politics rather than the contents - or 'prolocutors-strong' as they have a fuller set of policies and confidently step on the territory of established parties. Clearly, the most famous of such parties was Forza Italia - the party put together by Silvio Berlusconi in 1994 against the backdrop of a seriously weakened Italian centre-right. Parties based on the project of newness have been particularly numerous and successful in the new democracies of Central and Eastern Europe. Yet, the project has had much wider appeal and we would speculate that the formula will continue to be used successfully by upcoming and even established parties in the midst of deideologized political competition of contemporary democracies. ${ }^{1}$

[Table 2 about here]

While our core argument has substantial global relevance, we focus on four examples of particularly successful parties based on the project of newness from the Baltic states. We begin with a short overview of these parties. The second section analyses the policy positions of the parties using the data from two surveys - public opinion polls conducted in the framework of 2004 European Election Study and an expert survey conducted by Kenneth Benoit and Michael 
Laver in late 2003 and early 2004. Thereafter, the results based on quantitative data are contrasted to qualitative analysis of the parties in question, mostly based on evidence collected from interviews with party representatives and secondary sources. Analysis of expert survey data on the parties' positions on various issues shows that they failed to stand out amongst other major parties. The same conclusion appears from an analysis European Election Study data on the most important problems mentioned by the supporters of the parties. Both qualitative and quantitative evaluation of party positions leads us to conclude that at least three of the parties did not stand for much more than 'newness'. They advocated purification of their countries' politics - for instance, from corruption - while remaining in the ideological mainstream and keeping a safe distance from antisystem messages. The article concludes with a theoretical discussion on the general feasibility of newness as a project for new political parties anywhere. While three of the parties analysed here come close to being benchmark parties of newness, many others identified in the conclusion approximate the model. Therefore, the results of this study are relevant for understanding party politics and political competition everywhere even if the geographical scope of this study happens to be rather narrow.

\section{Four Highly Successful Parties Based on the Project of Newness}

The beginning of the third millennium saw in the three Baltic countries the triumphant rise of several genuinely new parties - meaning parties with negligible links to established politicians (Sikk 2005). Even though the party system had been stable in none of them, there had been important differences in the patterns 
of instability - particularly in Latvia, new parties had been more common than in Estonia and Lithuania. In 1998, the New Union (Social Liberals) was established in Lithuania by Artūras Paulauskas, the runner up in the 1997/98 presidential elections. The party won $19.6 \%$ of the vote in 2000 parliamentary election and Paulauskas became the speaker of the Seimas. In 2002, the New Era party was established in Latvia by Einars Repše, the former president of the Bank of Latvia. The party soon won the parliamentary election and Repše became the country's prime minister. In 2001, a political youth organization Res Publica was reorganized into a political party, becoming one of the two largest parties in the Estonian parliament following the 2003 elections with its leader, Juhan Parts, also taking the helm of government. In 2004, Lithuania witnessed the rise of another very successful new party - the Labour Party, which again became the largest party in Lithuanian parliament. The party was established and led by a wealthy Russian-born businessman Viktor Uspaskich, who became the minister of economic affairs following the formation of a coalition cabinet.

The four parties mentioned above were different in many respects. In contrast to its southern counterparts, the Estonian Res Publica never revolved around a single leader. Rather, the party was often impaired by difficulties in finding leaders who were simultaneously able and popular. In contrast to the lavish electoral campaigns of the other three, that of the New Era stood out as rather frugal. Perhaps as a consequence, uniquely among the four, the party managed to retain much of its popularity beyond the next elections. On the other hand, the original thriftiness is surprising as the New Era's membership was around ten times smaller than that of the others (Sikk 2004). In turn, Lithuania's New Union and the Labour Party have struggled to stay afloat while the Res Publica had to merge 
with an established party just three years after entering the Estonian parliament. While the New Union's Paulauskas left the post of parliamentary chair only in 2006, Parts, Repše and Uspaskich had to relinquish their posts very soon. In April 2005, Parts had to step down both as the prime minister and as the party chair. He did not oversee the party's merger with the Pro Patria party but returned to the cabinet as the minister of economic affairs and communications following a parliamentary election in 2007. In December 2004, the New Era returned to Latvian government for a single year, with Repše becoming the minister of defence. He returned to the cabinet - headed by another member of the party - as the minister of finance in 2009 while the party had changed leaders twice by then. Viktor Uspaskich, the leader of the Labour Party started to face accusations of conflict of interest and serious irregularities in his party's finances already in 2005. He has had an embattled political career ever since - including a selfimposed exile in Russia to avoid being prosecuted in Lithuania and running for the European Parliament in 2009 partly motivated by the need to regain immunity from criminal proceedings. Yet, the Labour Party has managed to retain some of its popularity.

In the face of these differences, the parties shared a striking similarity of emphasising newness in their maiden elections. In the case of New Era, 'new' is included in the name. One of the main slogans of Res Publica's electoral campaign was the somewhat enigmatic 'new politics'. The New Union (Social Liberals) was part of the 'New Politics Block' endorsed by the president Valdas Adamkus. As we will see below, the project of newness was essentially the only factor to distinguish these three parties from some of the major political parties in their respective countries. While the Lithuanian Labour Party also voiced calls for 
getting rid of the ruling clique and rooting up corruption, it went beyond the notion of newness in emphasising its broadly populist electoral pledges. ${ }^{2}$

\section{Quantitative Evaluation}

One way to assess the issues represented by new parties is to analyse the positions of its voters. The 2004 European Election Study surveys from the three countries provide a good comparative dataset, especially for Estonia and Latvia. The Lithuanian survey design was somewhat different and it was conducted three and the half years after the success of the New Union (Social Liberals). The party was no longer truly new and, more importantly, its support had diminished. There were only 32 respondents supporting the party that made a reliable analysis difficult. Therefore, we chose to analyse the voters of the Labour Party in 2004 European Elections. Recollection of preference in last national elections is used for Estonia and Latvia; for Lithuania, the analysis relies on the question on prospective electoral choice as the upcoming parliamentary election was much closer to the survey than the preceding one.

If a new party came about because of new social divides or significant new issues, we would expect their supporters to be concerned about different problems facing the country than are the voters of established parties. The main message of Tables 3 and 4 - based on open-ended questions in public opinion surveys - is that the most important problems facing the country mentioned by Res Publica voters in Estonia and New Era voters in Latvia were not very different from the ones mentioned by other respondents. Res Publica's voters attributed somewhat higher 
salience to wage levels while the concern for employment and pensions was somewhat lower than among the rest. That may underline the party's programmatic leaning towards market liberalism (i.e. close to the Reform Party) or simply related to the fact that the share of people in full time employment among its voters was above the average. The pattern in Latvia is fairly similar compared to average, New Era's voters stressed wages more and social problems (unemployment, pensions, poverty) less frequently. Even though there are slight discrepancies from the overall pattern of problems mentioned, the opinion surveys very clearly suggest that the parties did not stand for new social issues. In both cases, there is some indication that the style of politics was the real distinctive factor. Res Publica's voters mentioned the conflicts in party politics marginally more frequently than supporters of other parties, while New Era's supporters mentioned the government in general as a problem more often.

[Table 3 about here]

[Table 4 about here]

The Lithuanian Labour Party seems to be more distinct from their competitors (Table 5). The overall impression from the data is that its voters were remarkably materialist in their orientations: the frequency of mentioning higher wages, fighting unemployment and lower prices is most striking, while questions of economic efficiency, corruption, crime and health care caused less concern than among the total population. The fact that the salience attributed to the above issues was coupled with above average yearning for lower taxes match the overpromising tendencies of the party.

[Table 5 about here] 
An alternative test on the question of distinguishing issues is based on Benoit \& Laver (2006) expert survey data, conducted in late 2003 and early 2004. Expert surveys have their shortcomings - for instance, the judgements are not based on strictly standardized criteria, it is unclear whether they measure party preferences (in programs or manifestoes) or actual behaviour (in government) and the exact time the judgements refer to is open (see Budge 2001: 75). Nevertheless, Benoit \& Laver's is the best comparative dataset at hand on party policy positions around that time. Also, we can contrast the results of the expert survey with the results of an independent test looking at party voters presented above.

Figures 1 to 3 map the positions of Baltic parties in issue areas closest to traditional cleavages as discussed by Lipset \& Rokkan (1967), with the addition of the more recently surfaced environmental cleavage. In none of these do the new parties differentiate clearly, indicated by the fact that the parties are never placed on the edges of the spectra or occupy positions clearly distinctive otherwise. In most cases the parties lie close to parties that they fought on the same electoral ground. Res Publica tends to be close to the market liberal Reform Party (Ref). In Latvia, the proximity of New Era to the People's Party (TP) is even more evident. New Union (Social Liberals) tends to be close to the Social Democratic Party (LSDP) of former president and long-time prime minister Algirdas Brazauskas. Unsurprisingly, Res Publica seriously considered a merger with the Reform Party in 2004 and the New Union joined the Social Democrats in an electoral coalition for 2004 parliamentary elections. At the same time, while the New Era and the People's Party have sat together in Latvian Cabinets, there has always been much bad blood between the two parties - reflecting the fact that the New Era emerged 
as a reaction to the deficiencies of the then governing People's Party in the first place.

The expert survey included further issue dimensions not shown on the figures (for a full list, see Appendix) - in just a few of these did the new parties appear near the boundaries or otherwise distinctive. The Res Publica occupied a marginal position regarding decentralization, but was still very close to the Reform Party. However, the issue never was particularly important for the party. The New Era had the marginal positions regarding media freedom and decentralization - very clearly on both accounts. Especially the position on media freedom is indicative of its resolute stance on fighting corruption. However, it is difficult to tie that dimension down to cleavages or social issues. The New Union failed to differentiate clearly from other major Lithuanian parties on any issues; it was constantly very close to the Social Democratic party.

[Figures 1 to 3 about here]

Based on factor analysis of party positions on all 16 different issues covered in the expert survey, ${ }^{3}$ principal components of policy positions were derived. The factors combined different issues in the three countries. In Estonia, the primary Euroliberal dimension is complemented by a national-conservative one. In Latvia, liberalism is coupled with nationalism on the first dimension, complemented by urban-rural divide on the second. In Lithuania, the primary dimension combines national and religious issues, while the second connects Europhile attitudes with the promotion of urban interests.

On these compound factors, the new parties still fail to differentiate clearly (see Figure 4 to Figure 6). Only the Latvian New Era seems to be marginal on both 
factors, but it is quite close to People's Party (TP in Figure 5). As they fail to differentiate on any issue that could be connected to social divides (see Figure 1 to Figure 3) we can reject a hypothesis of social divides or cleavages giving rise to these new parties. The fact that such parties emerged in all three countries and became key players in their respective political systems strongly cautions against an assumption that it is primarily social cleavages that give rise to significant new parties.

[Figure 4 to Figure 6 about here]

\section{Qualitative Evaluation}

For all the four parties the defining feature was newness with a degree of anticorruption and mild anti-establishment stance. That clearly does not constitute a new ideology and is even less connected to either new or previously ignored social divides. At best, the parties were addressing a new issue of corruption and government inefficiency; yet especially Res Publica's and the New Union's stance against established parties was not particularly sharp and tackling corruption while significant - was an objective among others rather than an overarching theme. ${ }^{4}$ All of the parties were quite open to compromises in coalition formation following their first elections. Following the downfall of Repše government and a spell in opposition even the New Era joined its arch enemy People's Party in government. $^{5}$

Among the parties analysed, the Latvian New Era is the most obvious case of fighting in an occupied ideological territory. It has usually been characterized as 
mildly nationalist neo-liberal party and is hence very similar to the People's Party in policy positions. In interviews with representatives of Latvian political parties, no attempt was made to distinguish the parties with regard to programs - neither by the representatives of the New Era, those of other parties or neutral experts. Despite being perceived as almost identical with regard to party programs, the cooperation between the parties has constantly been very difficult and the merger of the ideologically close parties has always been clearly out of question. The People's Party was seen by the New Era as one of the main culprits behind corruption and its former leader Andris Šķēle as one of the key oligarchs pulling the strings of Latvian party politics. Despite sharing the cabinet table, the New Era stayed true to its harsh anti-plutocratic rhetoric.

The ideological background of the Res Publica party was somewhat more complicated (see Taagepera 2006 for more). In the run up to its first national elections the party was slightly torn between neo-liberal nationalists who made up the core initiative group of the party and centrists who advocated giving a more human face to Estonian free market capitalism without professing a turnaround in economic policies. In either case, the party was contesting elections in an occupied territory - the neo-liberal nationalist niche had been filled by Pro Patria Union for years and free market capitalism with a more human face had been the declared aim of the Moderates (once and now again the Social Democratic party). ${ }^{6}$ Later, when sharing governmental responsibilities, Res Publica moved closer to the market liberal Reform Party. The two even planned a merger that was eventually rejected by the Reform Party as the support ratings of Res Publica plummeted in 2004 (Pettai 2006). 
Of the two Lithuanian cases, the Labour Party basically ran on a strongly populist ticket (Ramonaite 2006) - promising to rid the country of corruption, decrease the price of heating, raise minimum salaries, tax-free income and pensions, provide generous mortgages for the young, exempting new enterprises from paying tax for years, introducing majoritarian electoral system and direct mayoral elections (Septyte 2004). In that, it competed for the disenchanted rural vote with the impeached former president Paksas's Liberal Democratic Party (Ramonaitė 2006: 85, Septyte 2004, Balockaite 2009: 19) Similarly, the New Union (Social Liberals) was in programmatic terms hardly distinguishable from the Social Democrats as they joined in a coalition for 2004 elections. Like any party, the New Union can be pinned down ideologically, given sufficient effort. However, that would obscure the fact that as for many other political parties, the ideology may take a back seat to other driving forces. In the words of Lithuanian political scientist Antanas Kulakauskas: 'The New Union was established not because somebody came up with new ideas ... but because people surrounding the party's popular leader ... decided to establish an organization. And it was only [afterwards] that they started thinking of an ideological doctrine to suit the organization.' (BBC Worldwide Monitoring 2004). For these reasons, any evaluation of programmatic positions of the New Era, the New Union (Social Liberals) and the Labour Party may be criticized, arguing that the essence of these parties has never really been their programs but the personal ambitions of their charismatic leaders (Ramonaite 2006). However, that counterargument would exactly reiterate the ambiguous importance of new or old ideologies in party competition. 
Both quantitative and qualitative assessment of the highly successful new parties point in the same direction - the parties were not advocating any new ideologies but rather challenging the old parties on their territory. Thus, they emerged as challengers or purifiers, with the crucial distinction that they did not attempt to cleanse any ideologies but rather improve the style of politics.

\section{Discussion: Newness as a Project}

Newness as a project has some very advantageous properties for political parties. It promotes the cause of change, but in an indistinct direction, thus having the potential to appeal to broad groups of the more or less discontented. As it may be fairly vague on specific policy commitments, the information costs of transferring the key message to the voters are much lower than with ideological or even issue based projects. It may require great effort to explain why particular policies are beneficial for individuals or a country; change 'for the better' is good by definition.

When combined with being ideologically in the mainstream, the project of newness entails low risks of scaring off potential supporters who might be afraid of too drastic changes in policy directions. This is particularly relevant given the socio-economic context at the time when the parties discussed emerged. The Baltic voters had just learned to cope with the newly established market economies - even those who did not feel well off had learned their strategies of survival and might have been afraid of too radical political forces. Besides the political proximity, the success potential of a party matters for voters - parties of 
the mainstream can more credibly claim to have better chances than parties at the fringes.

Clearly, the emphasis on newness with little new in terms of content would ceteris paribus have little potential for mobilising voters. For such a party to be successful, a strong combination of some other resources than just an appealing program or project is needed. Remarkably, the blend of resources utilized by the parties analysed here differed. The success of the New Era, the New Union (Social Liberals) and the Labour Party could to a great extent be credited to the charisma of party leaders, yet the project of newness is not necessarily combined by the charismatic presence of a towering political entrepreneur. For Res Publica, the key was a combination of considerable financial resources spent on electoral campaign as well as the competence and mild likeability of party leaders - former State Auditor Juhan Parts and Rein Taagepera, an eminent political scientist who served as the initial caretaker leader (see Taagepera 2006). In all cases, the willingness of donors to back the party - or the prospective leader in case of the New $\mathrm{Era}^{7}$ - signalled the feasibility and moderateness of the parties to voters.

Still, a question remains: why should voters go for such vague options?_The above discussion may seem to underestimate the level of sophistication among the Baltic electorates. For one, we may seem suggest that the voters do not pay much attention to programmatic profiles of political parties and focus on the personal qualities of aspirant leaders instead. However, the feasible policy space in modern European democracies has been argued to be constricted due to the pressures of globalization and Europeanization (see Blyth \& Katz 2005: 34, 41-44, Gray 2008). Thus, it may be all too rational for voters to focus on the personal appeal, 
integrity or technocratic ability of party leaders. For the most part, the incumbents had followed their electoral pledges and had managed to generate economic growth. Thus, there seems to have been little reason to reject them on programmatic grounds. At the same time, the achievements had been clouded by a perception of intolerably high levels of corruption, political scandal, inefficiency and social costs. Therefore, promising a new style of politics and only fine tuning policies essentially matched the programmatic expectations of the Baltic electorates.

While in this article we have opted for an in-depth analysis of four cases, the examples of parties exploiting newness more or less strongly are certainly not limited to the Baltic states. The Slovak Smer (Haughton 2004, Deegan-Krause 2007, Rybář \& Deegan-Krause 2008), and two recent Bulgarian parties - National Movement Simeon II (Peeva 2001, Barany 2002) and GERB (Stoychev 2008, Stefanova 2008) - are some of the most prominent examples from Central and Eastern Europe. ${ }^{8}$ The thoroughly reconfigured Polish centre-right - primarily the Civic Platform and the Law and Justice party - in 2001 parliamentary elections focussed on corruption and made some good use of the novelty factor in their campaigns (Szczerbiak 2002, 2003). More recently, in 2008, the celebrity-based National Resurrection Party - essentially employing the project of newness finished third in Lithuanian parliamentary elections and snatched the seat of the

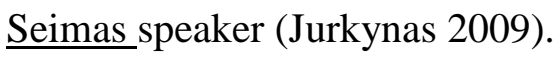

One may argue that countries in Central and Eastern Europe constitute a special case due to their communist legacies. However, party competition in Italy - a long-standing democracy with a party system dominated by relatively new parties 
- suggests striking similarities to that in the Central and Eastern Europe. Forza Italia, established in 1994 was in many respects very similar to the new Baltic parties analysed here. The party ran on an anti-corruption ticket, under a dominant leader, was programmatically flexible and - most importantly - stressed its newness (Hopkin \& Paolucci 1999, Farrell 1995). Therefore, perhaps one should think of Western Europe as a 'special case' due to the strong impact the legacy of long democratic traditions has on politics and party system stability there? Especially given the political scientists' objective to devise general theories to explain democratic politics anywhere - including future democracies - one has to take the experiences of young democracies seriously in theory building. It has been argued that new democracies might be the ones setting the future standards of party development (see van Biezen 2005: 169). Relaxing the assumptions in models of new party emergence by allowing for projects that are not ideologically novel - even in a sense of purification - would not ignore the realities of longstanding democracies, but would enable us to understand both them and the newer democracies better.

At the very least, this paper strongly demonstrates the need to look beyond social divides when searching for explanations for new party success in Central and Eastern Europe. There is evidence that the appeal of 'newness' extends beyond new and revamped party systems. Important parties of different programmatic persuasions have plumed their names with the adjective 'new' all over the world most prominently the British New Labour. ${ }^{9}$ Other examples include the Canadian New Democratic Party (established 1961), the Greek New Democracy (1974) and the French New Centre (2007) - all significant players in their countries' politics. Belgium, Denmark, Korea, Mexico, Sweden and Taiwan all have had smaller 
(some now defunct) parliamentary parties with the adjective 'new' in their name. Japan had at least seven parliamentary parties in the $20^{\text {th }}$ century with 'new' or 'renewal' in their title (Klein 2001). Remarkably, in 2008, there were hints of the project of newness even in the Democratic primary campaign of Barack Obama (Birnbaum 2008).

\section{Conclusion}

What do the parties analysed in this article teach us about new party theory? The most important lesson is that new parties are not necessarily a product of social or value change and cannot at times be tied down to cleavages. Newness in itself can be a viable project for a political party.

Models of new party emergence based on social or value change cannot explain the four cases. However good a predictive model at disposal, one cannot detect the demand for these parties by looking at value change or social heterogeneity that would misconstrue their reason of being. The 'issue' these new parties primarily stood for - newness - is by definition impossible to incorporate by old parties. The fact that several of such parties became highly successful in the three countries stresses the need to take a critical look at new party theory - in particular if we aim at one covering all democratic multi-party systems. For that, considering the possibility that new parties may be of a challenger or purifier type provides a better starting point. However, new parties fighting in an already occupied ideological territory may sometimes not be concerned with purifying the ideology. They might not differ much from old parties regarding their policy 
positions. Inhabiting the same political niche can also occur when the new parties simply try to convince the voters that they are better than the old ones in some other respects - for instance capability or integrity of their leaders.

While stressing the importance of non-programmatic factors behind the development of new parties, this article does not intend to argue that all significant new parties fall into the category of newness. During the last decade, new parties of other types have achieved success from all corners of the political spectrum in post-communist countries - the Greens (in the Czech Republic and Estonia), radical right parties (Greater Romania Party, Ataka [Bulgaria], Jobbik [Hungary], League of Polish Families), populist left (Self-Defence in Poland) etc.

What we do call for is a pluralist approach - while cleavages and politicization of issues go a long way in explaining political competition they are not able to explain all major developments. We agree that old parties can incorporate new issues - and if they seriously underestimate new demands, new parties may take over (Hug 1996, 2001). However, it is important to stress that embracing new issues can be difficult - because of legacies, party images, leaders' and voters' preferences etc. In case the incumbents themselves are the issue, its incorporation becomes virtually impossible. Ridiculing the new party's arguments remains the only option for existing parties - a poor one if the perceived levels of corruption and administrative inefficiency are high and the incumbents have used up their credit of trust. 


\section{References}

Balockaite, Rosa (2009) 'Can You Hear Us?: The Lower Class in Lithuanian Media and Politics', Problems of Post-Communism 56: 12-22.

Barany, Zoltan (2002) 'Bulgaria's Royal Elections', Journal of Democracy 13: $141-55$.

BBC Worldwide Monitoring (2004) 'Lithuanian analyst predicts election victory for populists and left-wing parties', Lietuvos Rytas 6 September.

Benoit, Kenneth and Michael Laver (2006) Party Policy in Modern Democracies. London: Routledge.

Biezen, Ingrid van (2005) 'On the theory and practice of party formation and adaptation in new democracies' European Journal of Political Research 44: $147-74$.

Birnbaum, Norman (2008) 'The Presidential Election of 2008', Political Quarterly 79: 344-53.

Blyth, Mark and Richard S. Katz (2005) 'From Catch-all Politics to Cartelisation: The Political Economy of the Cartel Party', West European Politics 28: $33-60$.

Budge, Ian (2001) 'Theory and Measurement of Party Policy Positions,' in Ian Buge, Hans-Dieter Klingemann, Andrea Volkens, Judith Bara and Eric Tanenbaum. Mapping Policy Preferences: Estimates for Parties, Electors, and Governments1945-1998, pp. 75-90. Oxford: Oxford University Press.

Deegan-Krause, Kevin (2003) 'Slovakia's Second Transition', Journal of Democracy 14: 65-79.

Deegan-Krause, Kevin (2007) 'Populism and the Logic of Party Rotation in Postcommunist Europe', in Ol'ga Gyárfášová and Grigorij Mesežnikov 
(eds) Visegrad Elections: Domestic Impact and European Consequences.

Bratislava: Institute for Public Affairs.

Farrell, Joseph (1995) 'Berlusconi and Forza Italia: New Force for Old?' Modern

Italy 1: 40-52.

Fitzmaurice, John (1999) 'The Slovak elections of 25th and 26th September 1998', Electoral Studies 18: 291-5.

Gamble, Andrew and Tony Wright (2008) 'Commentary: The End of New Labour?' Political Quarterly 79: 463-5.

Gray, Mark M. (2008) 'Promising Parties: Can Parties in Government still Deliver?' European Review 16 : 305-18.

Hanley, Seán (2008) The new right in the new Europe: Czech transformation and right-wing politics, 1989-2006. London: Routledge.

Hanley, Seán (2009) 'TOP Cats', Dr Sean's Diary, 23 July, http://drseansdiary.blogspot.com/.

Harmel, Robert and John D. Robertson (1985) 'Formation and Success of New Parties: A Cross-National Analysis', International Political Science Review 6: 501-23.

Haughton, Tim and Marek Rybář (2004) 'All right now? Explaining the successes and failures of the Slovak centre-right', Journal of Communist Studies and Transition Politics 20: 115-32.

Haughton, Tim (2004) 'Explaining the Limited Success of the CommunistSuccessor Left in Slovakia', Party Politics 10: 177-91.

Hauss, Charles and David Rayside (1978) 'The Development of New Parties in Western Democracies since 1945', in Louis Maisel and Joseph Cooper 
(eds). Political Parties: Development and Decay, pp. 31-57. Beverly Hills: Sage.

Hopkin, Jonathan and Caterina Paolucci (1999) 'The business firm model of party organization: Cases from Spain and Italy', European Journal of Political Research 35: 307-39.

Hug, Simon (1996) 'The emergence of new political parties from a game theoretic perspective', European Journal of Political Research 29: 169-90.

Hug, Simon (2001) Altering Party Systems. Strategic Behavior and the Emergence of New Political Parties in Western Democracies. Ann Arbor: The University of Michigan Press.

Jurkynas, Mindaugas (2009) 'The parliamentary election in Lithuania, October 2008', Electoral Studies 28: 329-33.

Kitschelt, Herbert (1988) 'Left-Libertarian Parties: Explaining Innovation in Competitive Party Systems', World Politics 40: 194-234.

Kitschelt, Herbert (1995) The Radical Right in Western Europe. A Comparative Analysis. Ann Arbor: University of Michigan Press.

Klein, Axel (2001) 'Japan', in Nohlen, Dieter, Florian Grotz and Christof Hartmann (eds). Elections in Asia and the Pacific: A Data Handbook Volume II: South East Asia, East Asia, and the South Pacific. Oxford: Oxford University Press.

Kopecky, Petr and Cas Mudde (1999) 'The 1998 parliamentary and senate elections in the Czech Republic', Electoral Studies 18: 415-24.

Krouwel, André and Onno Bosch (2004) 'Explaining the Emergence of New Parties: Cynical Citizens and the rise of populism', paper prepared for the 
workshop Kwaliteit van het leven en politieke attitudes, at the Politicologenetmaal 2004 in Antwerpen, 27-28 May.

Krouwel, André and Paul Lucardie (2008) 'Waiting in the Wings: New Parties in the Netherlands', Acta Politica 43: 278-307.

Laver, Michael (2005) 'Policy and the Dynamics of Political Competition', American Political Science Review 99: 263-81.

Lipset, Seymour M. and Stein Rokkan (1967) 'Cleavage Structures, Party Systems and Voter Alignments: An Introduction', in Seymour M. Lipset and Stein Rokkan (eds), Party Systems and Voter Alignments. Cross

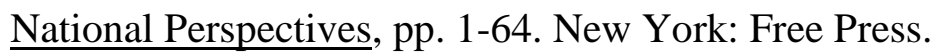

Lucardie, Paul (2000) 'Prophets, Purifiers and Prolocutors: Towards a Theory on the Emergence of New Parties', Party Politics 6: 175-85.

Mikkel, Evald (2006) 'Patterns of Party Formation in Estonia: Consolidation Unaccomplished', in Susanne Jungerstam-Mulders (ed) Post-Communist EU Member States: Parties and Party Systems, pp. 23-50. Aldreshot: Ashgate.

Müller-Rommel, Ferdinand (2002) 'Simon Hug, Altering Party Systems: Strategic Behavior and the Emergence of New Political Parties in Western Democracies', book review, $\underline{\text { Party Politics }}$ 8: 740-1.

Peeva, Ralitsa (2001) 'Electing a Czar: The 2001 Elections and Bulgarian Democracy', East European Constitutional Review 10: 51-61.

Pettai, Vello (2006) 'Estonia', European Journal of Political Research 45: 10941100.

Ramonaite, Ainè (2006) 'The Development of the Lithuanian Party System: From Stability to Perturbation', in Susanne Jungerstam-Mulders (ed) Post- 
communist EU member states: Parties and Party Systems, pp. 69-90.

Aldershot: Ashgate.

Rochon, Thomas (1985) 'Mobilizers and Challengers: Toward a Theory of New Party Success', International Political Science Review 6: 419-39.

Rybár̆, Marek and Kevin Deegan-Krause (2008) 'Slovakia's Communist successor parties in comparative perspective', Communist and PostCommunist Studies 41: 497-519.

Septyte, Milda (2004) 'Labor's populist promises fraught with national bankruptcy', The Baltic Times 2 September.

Siaroff, Alan (2003) 'Two-and-a-Half-Party Systems and the Comparative Role of the "Half", Party Politics 9: 267-90.

Sikk, Allan (2004) 'Successful new parties in the Baltic states: similar or different?' paper presented at the conference The Baltic States: New Europe or Old? University of Glasgow, 22-23 January.

Sikk, Allan (2005) 'How unstable? Volatility and the genuinely new parties in Eastern Europe', European Journal of Political Research 44: 391-412.

Smith, Gordon (1991) 'In search of small parties: Problems of Definition, Classification and Significance', in Ferdinand Müller-Rommel and Geoffrey Pridham (eds) Small Parties in Western Europe. Comparative and National Perspectives, pp. 23-40. London: Sage.

Stefanova, Boyka (2008) 'The 2007 European elections in Bulgaria and Romania', Electoral Studies 27: 566-71.

Stoychev, Stoycho P. (2008) 'Europeanization of the Bulgarian Party System: Dynamics and Effects', CEU Political Science Journal 3: 2-24. 
Szczerbiak, Aleks (2002) 'Dealing with the Communist Past or the Politics of the Present? Lustration in Post-communist Poland', Europe-Asia Studies 54: $553-72$.

Szczerbiak, Aleks (2004) 'The Polish Centre-Right's (Last?) Best Hope: The Rise and Fall of Solidarity Electoral Action', Journal of Communist Studies and Transition Politics 20: 55-79.

Taagepera, Rein (2006) 'Meteoric trajectory: The Res Publica Party in Estonia', Democratization 13: 78-94.

Tavits, Margit (2006) 'Party System Change: Testing a Model of New Party Entry', Party Politics 12: 99-119.

Tavits, Margit (2007) 'Party Systems in the Making: The Emergence and Success of New Parties in New Democracies', British Journal of Political Science 38: $113-33$.

Tavits, Margit (2008) 'Policy Positions, Issue Importance, and Party Competition in New Democracies', Comparative Political Studies 41: 48-72.

Učeň, Peter, Ol'ga Gyárfášová and Vladimír Krivý (2005) 'Centrist Populism in Slovakia from the Perspective of Voters and Supporters', Slovak Foreign Policy Affairs No.1: 28-47.

Willey, Joseph (1998) 'Institutional Arrangements and the Success of New Parties in Old Democracies', Political Studies 44: 651-68. 


\section{Appendix: Factors of Issue Positions in Expert Surveys}

Data from Benoit \& Laver (2006), analysed by author.

Table 1 Estonia: Factors of Issue Positions in Expert Surveys

\begin{tabular}{|c|c|c|c|}
\hline & \multicolumn{3}{|c|}{ Component } \\
\hline & 1 & 2 & 3 \\
\hline Media Freedom & -.976 & -.025 & -.082 \\
\hline Privatization & .938 & .150 & .266 \\
\hline EU joining & .937 & -.031 & -.224 \\
\hline Foreign Land Ownership & -.866 & .225 & -.368 \\
\hline Taxes v. Spending & 695 & .368 & .393 \\
\hline Nationalism & .036 & .861 & -.311 \\
\hline Former Communists & .344 & .803 & .041 \\
\hline Religion & .104 & -.791 & -.121 \\
\hline Social & -.621 & .708 & .165 \\
\hline Decentralization & -.078 & .243 & .901 \\
\hline Urban-Rural & -.363 & .332 & -.775 \\
\hline Environment & .685 & -.120 & .668 \\
\hline Initial eigenvalues & $\underline{5.596}$ & $\underline{2.889}$ & 1.904 \\
\hline Extraction meth & d: prin & iponent & Rotate \\
\hline
\end{tabular}

Table 2 Latvia: Rotated Component Matrix

\begin{tabular}{llll}
\hline & \multicolumn{2}{l}{ Component } & \\
\cline { 2 - 4 } & 1 & 2 & 3 \\
\hline Decentralization & $\mathbf{. 9 6 2}$ & -.192 & -.055 \\
Taxes v. Spending & $\mathbf{. 9 5 8}$ & -.014 & .258 \\
Privatization & $\mathbf{. 9 2 0}$ & -.017 & .342 \\
Former Communists & $\mathbf{. 8 9 4}$ & .193 & .364 \\
EU joining & $\mathbf{. 8 7 6}$ & -.106 & .332 \\
Nationalism & $\mathbf{. 8 2 8}$ & .480 & .217 \\
\hline Urban-Rural & .233 & $\mathbf{. 9 3 0}$ & .123 \\
\hline
\end{tabular}




\begin{tabular}{llll}
\hline Foreign Land Ownership & .271 & $\mathbf{. 8 6 1}$ & -.176 \\
Environment & .452 & $\mathbf{- . 8 0 2}$ & .009 \\
\hline Social & .164 & -.026 & $\mathbf{. 9 3 7}$ \\
Religion & -.463 & .072 & $\mathbf{- . 8 4 7}$ \\
Media Freedom & .346 & -.456 & .073 \\
\hline$\underline{\text { Initial eigenvalues }}$ & $\underline{6.444}$ & $\underline{\underline{2.779}}$ & $\underline{\underline{1.315}}$
\end{tabular}

Notes: Extraction method: principal component analysis. Rotated component matrix; rotation method: varimax. Component scores with absolute value over 0.6 in bold.

\section{Table 3 Lithuania: Rotated Component Matrix}

\begin{tabular}{llll}
\hline & \multicolumn{2}{l}{ Component } & \\
\cline { 2 - 4 } & 1 & 2 & 3 \\
\hline Religion & $\mathbf{- . 9 7 3}$ & .102 & .127 \\
Nationalism & $\mathbf{. 8 8 5}$ & -.211 & .309 \\
Social & $\mathbf{. 8 7 5}$ & -.397 & -.188 \\
Media Freedom & $\mathbf{. 8 6 9}$ & -.024 & .484 \\
\hline EU joining & -.004 & $\mathbf{. 9 0 2}$ & -.221 \\
Urban-Rural & .381 & $\mathbf{- . 8 8 8}$ & .230 \\
Environment & -.454 & $\mathbf{. 7 5 3}$ & .380 \\
Foreign Land Ownership & .262 & $\mathbf{- . 7 0 2}$ & $\mathbf{. 6 0 5}$ \\
\hline Decentralization & .078 & .205 & $\mathbf{. 9 6 8}$ \\
Taxes v. Spending & -.027 & .377 & $\mathbf{- . 8 5 4}$ \\
Privatization & -.036 & .521 & $\mathbf{- . 8 1 2}$ \\
\hline Initial eigenvalues & $\underline{5.650}$ & $\underline{2.866}$ & $\underline{1.814}$ \\
\hline
\end{tabular}

Notes: Extraction method: principal component analysis. Rotated component matrix; rotation method: varimax. Component scores with absolute value over 0.6 in bold. 
Tables and Figures

Table 4 Lucardie's typology of new political parties

\begin{tabular}{|c|c|c|c|}
\hline & & $\begin{array}{r}\text { Occupies } \\
\text { an es }\end{array}$ & $\begin{array}{l}\text { aptured by } \\
\text { party? }\end{array}$ \\
\hline & & \pm & $=$ \\
\hline Ideological & Strong & Purifiers & Prophets \\
\hline & Weak & & Prolocutors \\
\hline
\end{tabular}

Table 5 Extended typology of new parties

\begin{tabular}{llll}
\hline & \multicolumn{2}{c}{ Occupies a niche captured by } \\
an established party? \\
\hline$\underline{\text { Strong }}$ & Purifiers & Prophets \\
\hline$\underline{\text { motivation }}$ & $\underline{\text { Weak }}$ & Project of & Prolocutors \\
& & newness & \\
\hline
\end{tabular}


Table 6 What do you think is the most important problem in Estonia? (\%)

\begin{tabular}{llll}
\hline & \multicolumn{2}{l}{ Voted in 2003 for } & \\
\cline { 2 - 3 } & an incumbent & Total \\
& parliamentary & Res Publica & \\
& party & & \\
\hline Unemployment, jobs & 22.5 & 16.2 & 22.5 \\
Wages and earnings & 11.1 & 18.4 & 12.8 \\
Welfare policy (social security, child benefits etc) & 12.4 & 13.8 & 12.4 \\
Other social conflicts, problems & 11.0 & 6.7 & 9.4 \\
Pensions, retirement policy & 6.9 & 3.7 & 5.7 \\
Any other topic & 3.3 & 2.8 & 4.0 \\
Economy or economic policy & 3.2 & 4.6 & 3.2 \\
Inter- and intraparty conflicts, disagreements, fights & 3.2 & 4.3 & 3.2 \\
Education & 2.9 & 2.4 & 3.0 \\
\hline $\mathrm{N}$ & 770 & 232 & 1606 \\
\hline
\end{tabular}

Source: European Election Study 2004, Estonian Survey (N=1606)

Notes: Problems mentioned by at least 3 per cent of respondents. 
Table 7 What do you think is the most important problem in Latvia? (\%)

\begin{tabular}{llll}
\hline & \multicolumn{2}{c}{ Voted in 2002 for } & \\
\cline { 2 - 3 } & an incumbent & Total \\
& parliamentary & New Era & \\
& party & & \\
& 24.1 & 20.2 & 24.5 \\
\hline Unemployment, jobs & 9.5 & 12.5 & 10.9 \\
Wages and earnings & 8.6 & 6.3 & 7.7 \\
Pensions, retirement policy & 7.7 & 5.3 & 7.3 \\
Poverty & 4.9 & 4.8 & 5.7 \\
Education & 5.5 & 4.3 & 5.2 \\
Inflation & 5.5 & 7.7 & 5.0 \\
The government (general) & 3.3 & 5.8 & 3.2 \\
Welfare policy & 3.3 & 2.9 & 3.0 \\
The economy (general) & 453 & 208 & 1000 \\
\hline $\mathrm{N}$ & & & \\
\hline
\end{tabular}

Source: European Election Study 2004, Latvian Survey (N=1000)

Note: Problems mentioned by at least 3 per cent of respondents. 
Table 8 What do you think are the important problems in Lithuania? (\%)

\begin{tabular}{llll}
\hline & \multicolumn{2}{l}{ Would vote in 2004 for } & Total \\
\cline { 2 - 3 } & an incumbent & & \\
& parliamentary & Labour Party & \\
& party & & 57.6 \\
\hline Unemployment & 51.2 & 64.4 & 54.6 \\
Wages and salaries & 46.7 & 63.7 & 52.5 \\
Efficiency of economy & 58.7 & 50.0 & 49.5 \\
Pensions & 45.2 & 50.7 & 48.2 \\
Taxes & 42.2 & 56.2 & 47.2 \\
Social justice & 45.2 & 46.9 & 46.5 \\
Health care & 49.7 & 46.9 & 45.7 \\
Corruption & 51.2 & 40.1 & 43.9 \\
Consumer prices & 34.3 & 52.4 & 43.2 \\
Crime & 47.9 & 40.8 & 42.3 \\
Social guarantees & 42.5 & 43.8 & 7.66 \\
\hline Average number of problems mentioned & 7.87 & 7.65 & 1005 \\
\hline N & 332 & 292 & \\
\hline Soure: Eut. & & \\
\hline
\end{tabular}

Source: European Election Study 2004, Lithuanian Survey (N=1005)

Note: Problems mentioned by at least 40 per cent of respondents. Several problems could be mentioned by respondents. 
Figure 1 Policy Positions of Estonian Parties - Major Social Issues

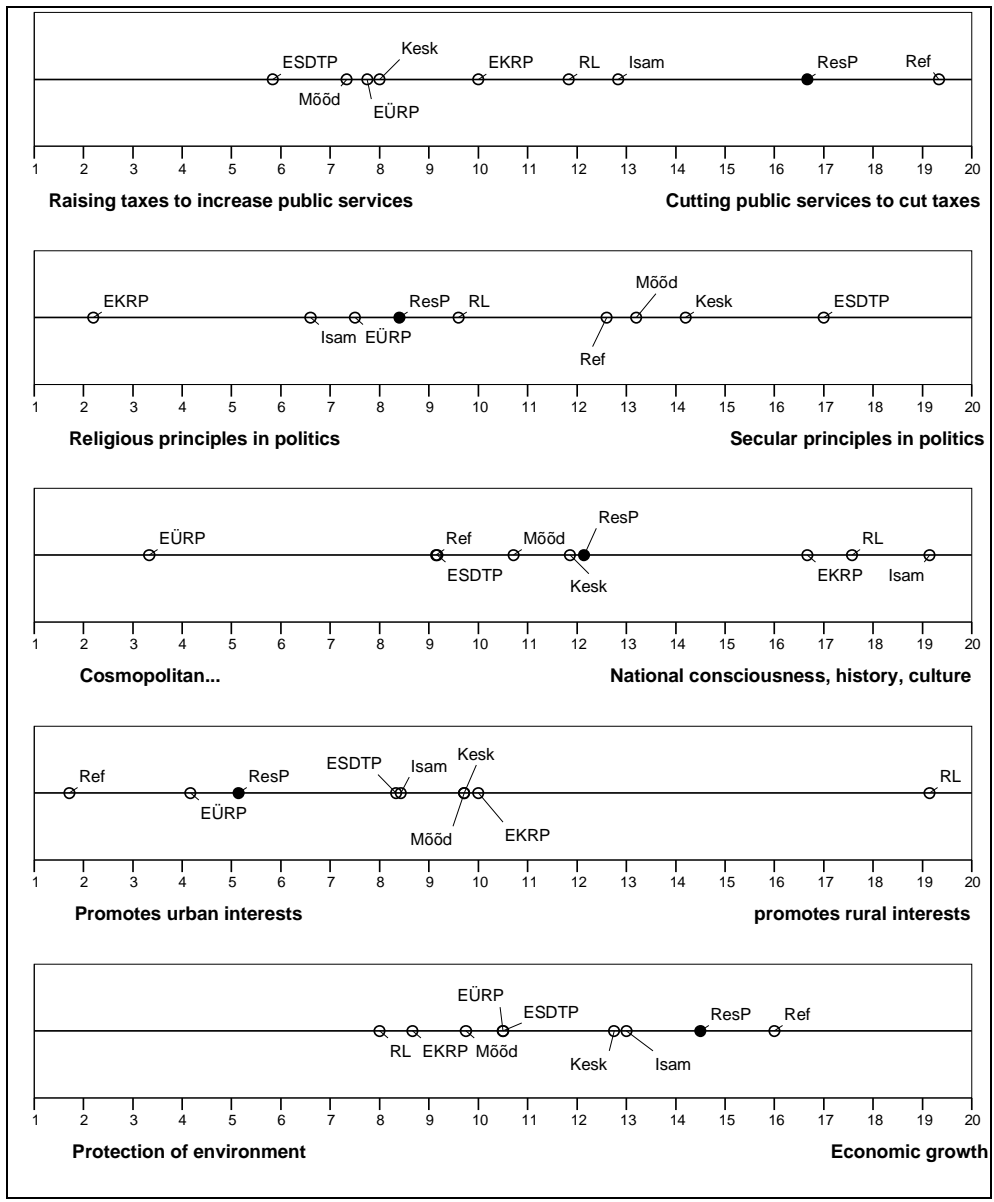

Source: Benoit \& Laver (2006).

Notes:

ESDTP: Social Democratic Labour Party

EÜRP: United People's Party

Isam: Pro Patria

Kesk: Centre Party

Mõõd: Moderates

Ref: Reform Party

ResP: Res Publica (filled circle)

RL: People's Union 
Figure 2 Policy Positions of Latvian Parties - Major Social Issues

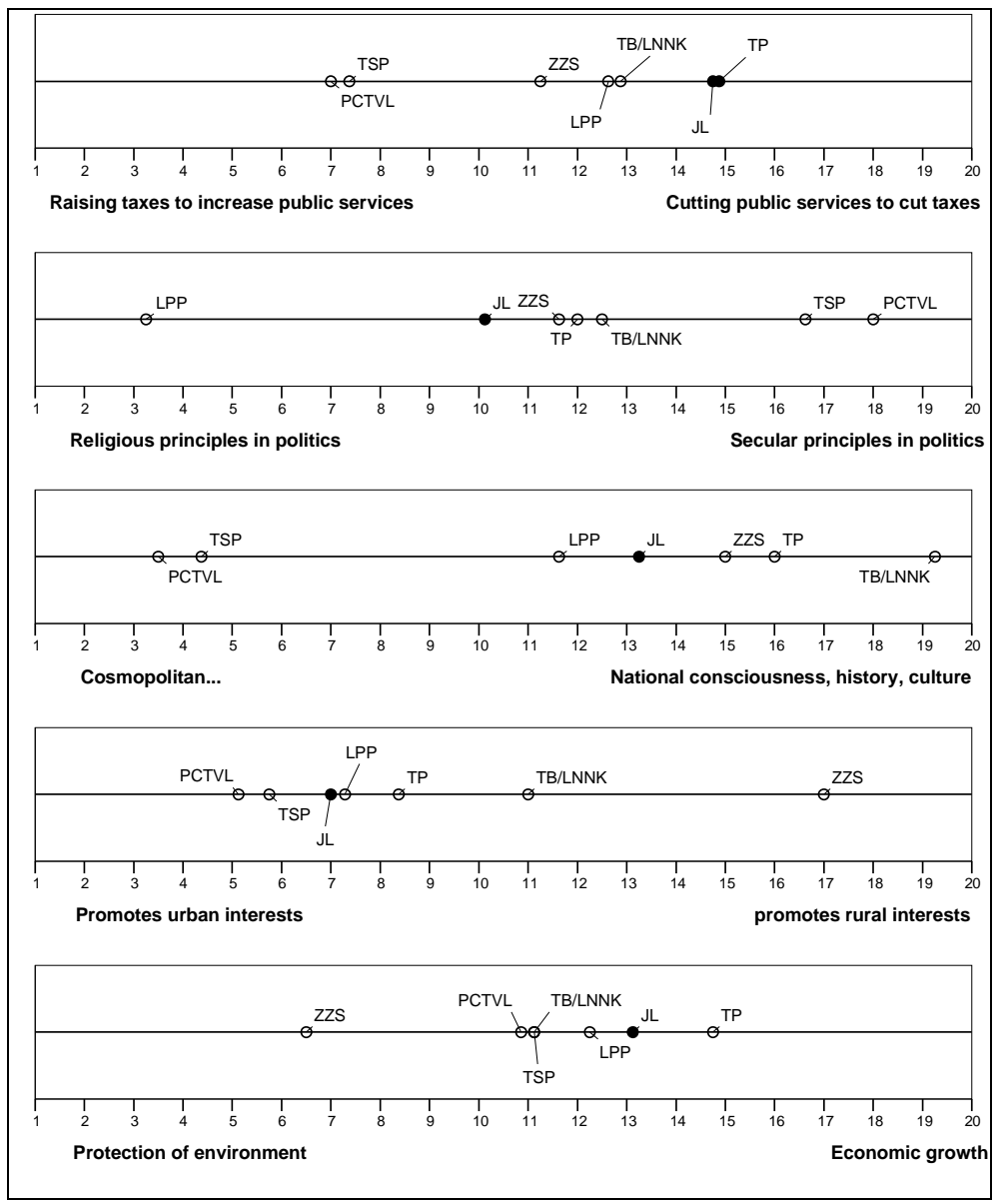

Source: Benoit \& Laver (2006).

Notes:

JL: New Era (filled circle)

LPP: Latvia's First Party

PCTVL: For Human Rights in a United Latvia

TB/LNNK: For Fatherland and Freedom

TP: People's Party

TSP: Popular Harmony Party

ZZS: Green and Farmers' Union 
Figure 3 Policy Positions of Lithuanian Parties - Major Social Issues

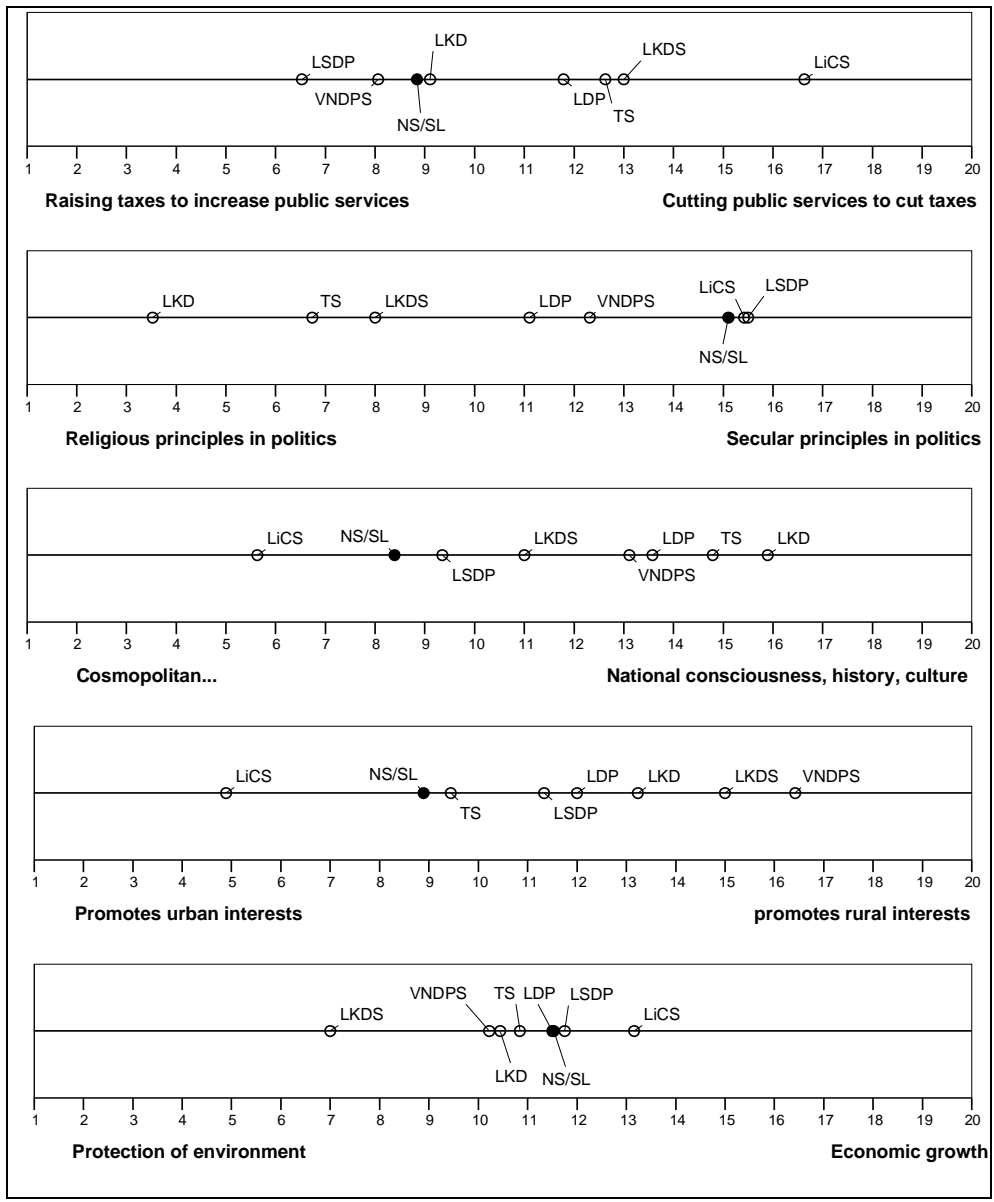

Source: Benoit \& Laver (2006).

Notes:

LDP: Liberal Democratic Party

LiCS: Liberal and Centre Union

LKD: Lithuanian Christian Democrats

LKDS: Union of Lithuanian Christian Democrats

LSDP: Social Democratic Party

NS/SL: New Union (Social Liberals) (filled circle)

TS: Homeland Union

VNDPS: Peasants and New Democracy 
Figure 4 Estonian Party Positions - Two Main Factors

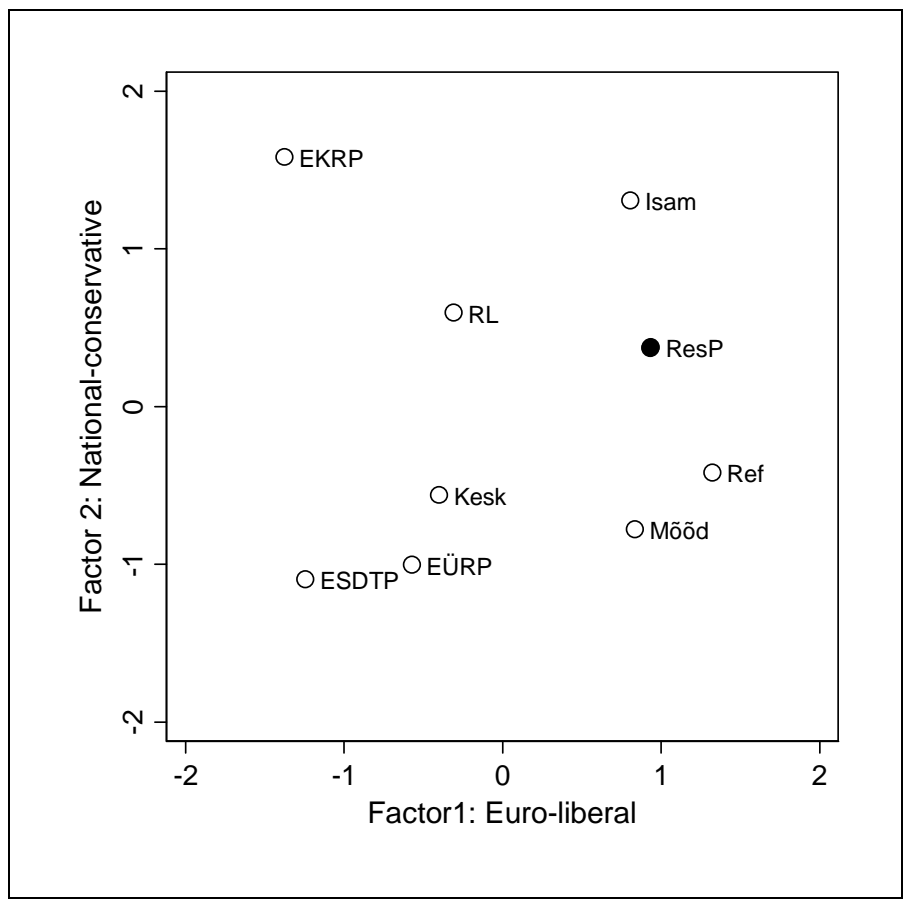

Note: Filled circle indicates Res Publica, abbreviations the same as Figure 1. Source: Author's analysis of data from Benoit \& Laver (2006). For rotated component matrices see Appendix.

Figure 5 Latvian Party Positions - Two Main Factors

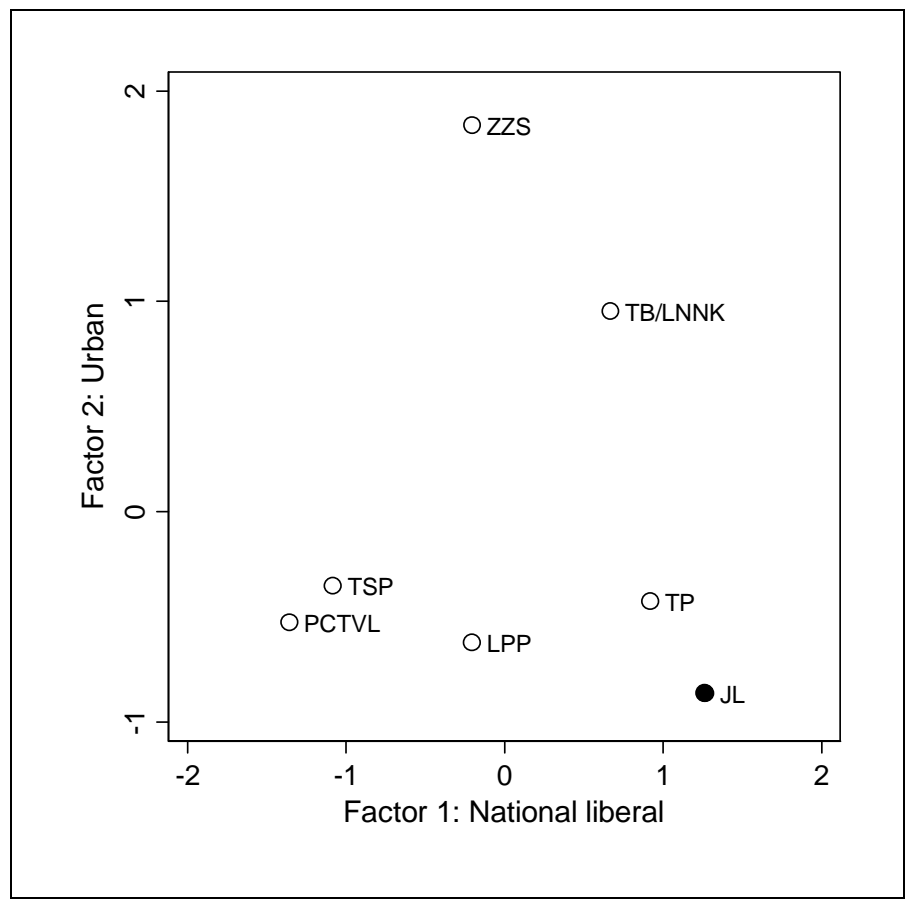

Note: Filled circle indicates New Era, abbreviations the same as Figure 2. Source: Author's analysis of data from Benoit \& Laver (2006). For rotated component matrices see Appendix. 
Figure 6 Lithuanian Party Positions - Two Main Factors

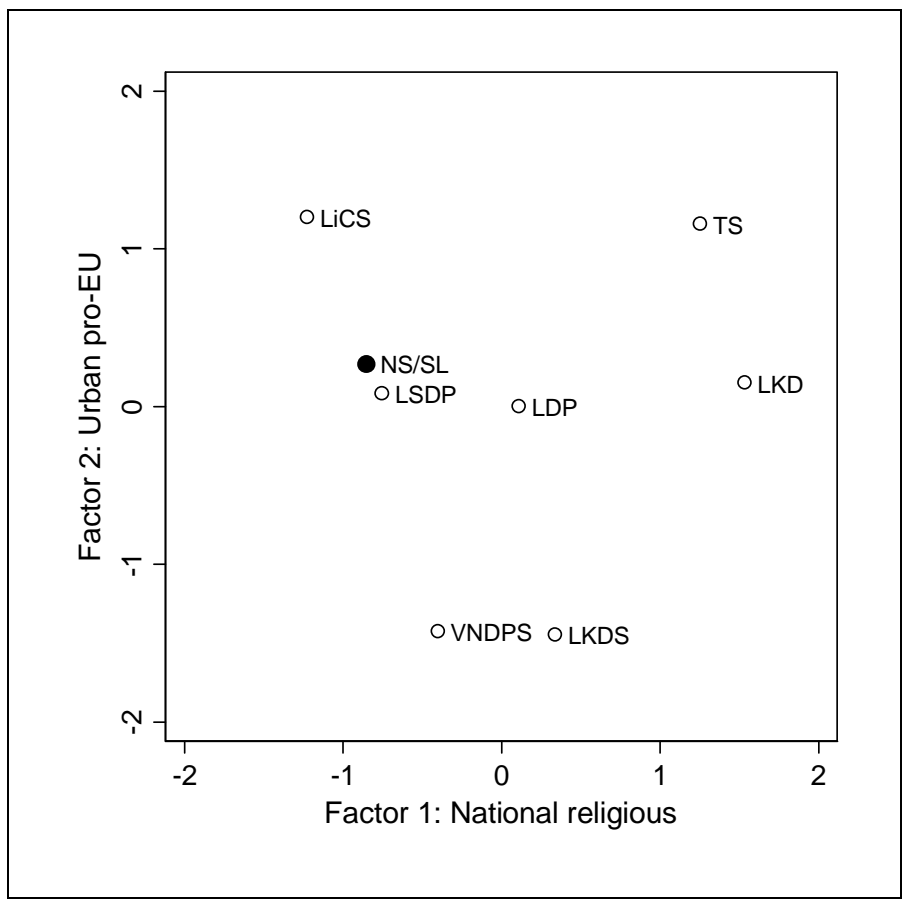

Note: Filled circle indicates New Union (Social Liberals), abbreviations the same as Figure 3. Source: Author's analysis of data from Benoit \& Laver (2006). For rotated component matrices see Appendix. 


\section{Acknowledgments}

Earlier version of the article was presented at the ECPR General Conference, Budapest, 8-10 September 2005. The author is grateful to the participants of the panel, Rein Taagepera, Seán Hanley and Vello Pettai for helpful comments. The research for this paper was assisted by the Targeted Financing Grant 0182573s03 of the Estonian Science Foundation.

\section{Notes}

${ }^{1}$ Krouwel \& Lucardie (2008) propose a five-way extension to Lucardie's original classification. They rename 'prolocutors' as 'advocates'. A broad category of ‘challengers' roughly combines 'purifiers' and 'parties of newness' in Table 2. Two further types of parties are introduced. First, ideologically vague 'reform' parties that wish to renovate the political system can fall into any cell in Table 2 excluding the one of 'prophets'. Second, 'idiosyncratic' parties are 'reflecting the personal inclinations and ideological eclecticism of the founders'; these can theoretically fall anywhere in Table 2. While the typology is useful for categorising new political parties, it does not have the ideological or issue novelty at its focus and hence the party of newness - the focal point of this article - can fall into several of the categories and possibly at the same time.

2 The relationship between populism and newness, and whether such parties are more likely to be populist than others in Table 2 are interesting research questions on their own right but fall outside the scope of this article. 
${ }^{3}$ The full wording of the questions is available in Benoit \& Laver (2006). For factor loadings of the issues see Appendix.

${ }^{4}$ It would not be appropriate to classify the parties studied here as merely anticorruption parties. While the issue did feature prominently in their campaigns and manifestoes, it never became the parties' raison d'etre - as witnessed by the most important issues mentioned by their voters in public opinion surveys presented above.

5 The relationship of the parties remained very hostile despite sharing governmental responsibilities.

${ }^{6}$ Here, Res Publica may appear to have been a "hinge party" (Smith 1991: 36, Siaroff 2003) squeezed between Pro Patria, the Reform Party and the Moderates. While it is arguable that Res Publica did not fully conform to the ideal type of party of newness, it should be borne in mind that the vaguely social democratic Moderates used to be close to the national conservative Pro Patria and market liberal Reform Party until the second half of 2000s (Mikkel 2006: 24).

${ }^{7}$ Repše declared his intention to form a new party some time before New Era was actually established - it was the most popular party in Latvia before it even had a tentative name. Prior to establishing the party, Repše expected a fee of 720,000 Euros to be paid by sponsors for leaving his post of president of the Bank of Latvia (Sikk 2004: 4-5). 
${ }^{8}$ Other, less successful parties with strong undercurrents of the project of newness include the Czech Freedom Union (Hanley 2008: 139, Kopecky \& Mudde 1999) and TOP09 (Hanley 2009), Slovak Alliance of the New Citizen (DeeganKrause 2003, Haughton \& Rybáŕ 2004, Učeň et al. 2005) Civic Understanding Party (Fitzmaurice 1999), and Slovenian Zares.

${ }^{9}$ In turn - and loudly echoing our argument about party competition on a shared ideological territory - it has been argued that the Conservative party under David Cameron was challenging the New Labour in 2010 “... on the basis of a claim to deliver New Labour policies better than the Labour party can." (Gamble \& Wright 2008: 464). 